\title{
Isolation of Cellulolytic Bacteria from Soil, Identification by 16S rRNA Gene Sequencing and Characterization of Cellulase
}

\author{
Faria Mahjabeen ${ }^{1}$, Sazzad Khan ${ }^{1}$, Naiyyum Choudhury ${ }^{2}$, M. Mahboob Hossain ${ }^{1}$, Trosporsha Tasnim Khan ${ }^{1 *}$ \\ ${ }^{1}$ Microbiology Program, Department of Mathematics and Natural Sciences, BRAC University, 66 Mohakhali, Dhaka-1212, Bangladesh, ${ }^{2}$ Bangladesh \\ Atomic Energy Regulatory Authority (BAERA), E-12/A, Shahid Shahabuddin Shorok, Dhaka 1207, Bangladesh
}

\begin{abstract}
Microbial Cellulases have an escalating demand in many industries and constitute a major group of the industrial enzymes. It has attracted the attention of many researchers because of its tremendous industrial applications including textile industry, pulp, and paper industry, laundry and detergent industry, food and animal feed industry. The present study pursues to unfold a novel cellulase that can overcome existing challenges in biorefineries as well as to reduce biofuel production cost. Therefore, soil from a dairy farm was screened for potent cellulase producers on carboxymethylcellulose agar. Out of 68 isolates, 31 expressed cellulase activity. The best isolate so far had an extracellular crude enzyme activity of $0.167 \mathrm{U} / \mathrm{ml}$ and specific activity of $0.333 \mathrm{U} / \mathrm{mg}$. The cell morphology, cultural characteristics, and biochemical tests presumptively identified it to belong to the genus Bacillus. Molecular analysis using 16S rRNA gene of the isolate indicated it to be Bacillus subtilis. The optimum $\mathrm{pH}$ and temperature for the activity of the crude enzyme were determined to be 5 and $65^{\circ} \mathrm{C}$ respectively.
\end{abstract}

Keywords: Bacillus subtilis, Cellulase, 16S rRNA

\section{Introduction}

Cellulose is a major component of plant biomass. Every year production of photosynthetic biomass is estimated to be approximately 40 billion tons, making cellulose the most abundant polysaccharide produced in the biosphere and also a renewable as well as a potential resource for bioconversion ${ }^{1,2}$. This biological conversion of the cellulosic biomass to fuels and chemicals offers a high yield of products vital to economic success and the potentiality for very low cost produce ${ }^{3}$. Cellulase is responsible for the bioconversion of cellulosic and lignocellulosic residues. It hydrolyses â-1, 4-glycosidic bonds in cellulose. The extensive intermolecular bonding pattern of cellulose creates a phenomenal crystalline substrate, particularly resistant to microbial degradation ${ }^{4}$. Hence, cellulolytic activity is a multi-complex enzyme system and complete enzymatic hydrolysis requires a synergistic action of 3 enzymes: endo-glucanase, exo-glucanase and glucosidase ${ }^{5}$. These enzymes act sequentially in the synergistic system and efficiently degrade cellulose converting it into an utilizable energy source. Thus, cellulases play a vital role in biomass utilization.

Although most efficient cellulase activities are observed in fungi, there is increasing interest in cellulase production by bacteria since they have a higher growth rate as compared to fungi and has good potential to be used in cellulase production ${ }^{6}$. Most common cellulolytic microorganisms include fungi like Trichoderma, Humicola, Penicillium, Aspergillus and among bacteria, Bacillus, Pseudomonas, Cellulomonas and within Actinomycetes, Streptomyces and Actinomucor ${ }^{7}$.

Few pieces of evidence from previous studies performed in Bangladesh reveals that at present due to the urbanization and rapid growth of population, municipal solid waste is raising in the amount causing a threat to the environment. It mostly consists of cellulosic organic content which could be easily biologically converted to bioresources using potent organisms from the studies, in order to prevent environmental pollution and public health hazards in urban areas. This makes cellulase research imperative in Bangladesh ${ }^{8}$. Also, celluloses have a high demand in the textile industry for sustainable washing as a finishing treatment in the denim garments in order to make them comfortable to wear ${ }^{9}$. Thus, cellulases are used in wide range of industries such as agriculture, detergents, fermentation, food, pulp and paper, textile and others. The need to import cellulases by means of expensive transportation or the usage of harmful chemicals instead of cellulases in the industries can be prevented if the enzyme is produced in Bangladesh in a substantial amount and expanding the economy thereby. New enzyme sources can be developed using emerging biotechnological tools to provide desirable enzyme features, which include increasing specific activities with more balanced synergism, better thermal stability, better resistance to environmental inhibitors and improved combination of various enzyme activities that maximize sugar yields at low $\operatorname{cost}^{3}$. Lignocellulosic biomolecules are also used as an alternative

*Corresponding author:

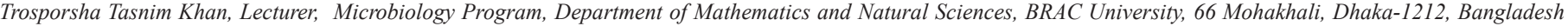
Telephone: +8801680043260,E-mail: trosporsha@bracu.ac.bd 
source of energy to prevent global warming and air pollution ${ }^{10}$. Although, cellulases have a wide range of industrial applications in Bangladesh, the obstacles to developing cost-effective processes for converting biomass to fuels and chemicals are yet to be fully realized. The aim of this research work included isolation, identification, and screening of bacteria with high cellulase activity from soil samples and optimization of different parameters such as optimum $\mathrm{pH}$ and temperature for better enzyme activity. The present study further aimed to obtain a cellulase producer that would allow cellulase production at low cost; that can be utilized in the industries that would passively reduce environmental pollution through biodegradation and cellulose decomposition.

\section{Materials and Methods}

Sample collection, isolation and primary screening of cellulolytic bacteria

Soil sample was collected from 'Bagan Bari Dairy Farm', Keranigonj. The samples were collected in a sterile container and stored at $4^{\circ} \mathrm{C}$ until use. Ten-fold serial dilutions of the soil sample were prepared in autoclaved saline water. One hundred microlitre sample from $10^{-4}, 10^{-5}$ and $10^{-6}$ dilutions were spread plated on Nutrient Agar (NA) plates. The NA plates were then incubated at $37^{\circ} \mathrm{C}$ for 24 hours. Pure cultures of bacterial isolates were transferred onto carboxymethylcellulose agar plates by needle inoculation and incubated for 48 hours. The carboxymethlycellulose agar medium used for isolation of cellulolytic bacteria contained $1.0 \%$ peptone, $1.0 \%$ carboxymethylcellulose (CMC), $0.2 \% \mathrm{~K}_{2} \mathrm{HPO}_{4}, 1 \%$ agar, $0.03 \%$ $\mathrm{MgSO}_{4} .7 \mathrm{H}_{2} \mathrm{O}, 0.25 \%\left(\mathrm{NH}_{4}\right)_{2} \mathrm{SO}_{4}$ and $0.2 \%$ gelatin ${ }^{11}$. After incubation at $37^{\circ} \mathrm{C}$ for 48 hours, the $\mathrm{CMC}$ agar plates were flooded with gram's iodine and allowed to stand at room temperature for around 10 minutes. The ratio of the clear zone diameter to colony diameter of CMC hydrolysis was measured ${ }^{6}$. The bacterial colonies having the lergest ratio were analyzed for cellulase activity.

\section{Estimation of cellulase activity and specific activity}

Cellulase activity was assayed using dinitrosalicylic acid (DNS) reagent by estimation of reducing sugars released from CMC solubilized in $0.05 \mathrm{M}$ phosphate buffer at $\mathrm{pH} 8$. Crude enzyme was added to $1.0 \mathrm{ml}$ of $1 \% \mathrm{CMC}$ (used as substrate) in $0.05 \mathrm{M}$ phosphate buffer $(\mathrm{pH} 4.8)$ and incubated in a water bath at $50^{\circ} \mathrm{C}$ for $30 \mathrm{~min}$. After incubation, the reaction was stopped by the addition of $1.5 \mathrm{ml}$ of DNS reagent, boiled at $100^{\circ} \mathrm{C}$ in a water bath for $10 \mathrm{~min}$ and were cooled under running tap water. Sugars liberated were determined by measuring absorbance at $540 \mathrm{~nm}$. Cellulase production was estimated by using a glucose calibration curve. Using equal volumes of distilled water and $0.05 \mathrm{M}$ phosphate buffer as blank, the absorbance was taken and a graph was plotted for the values of glucose concentration against the corresponding absorbance. One unit (U) of enzyme activity is expressed as the quantity of enzyme, which is required to release 1 ìmol of glucose per minute under standard assay conditions ${ }^{12}$.

Protein concentrations in the crude enzymes were determined by using the Folin Lowry method with bovine serum albumin (BSA) as a standard ${ }^{13}$. This was used to calculate specific activity.

\section{Presumptive identification of cellulase producing bacteria}

The best isolate was tentatively identified by means of morphological, cultural and biochemical characterization. The biochemical tests performed were: Carbohydrate fermentation (Sucrose, fructose, glycerol, maltose and D-xylose), Triple sugar iron agar test, IMViC test (Indole production test, Methyl red test, Voges- Proskauer test, Citrate utilization test), Urease test, Nitrate reduction test, Catalase test, Oxidase test, Casein hydrolysis test, Motility test, Gelatin hydrolysis test, Mannitol Salt Agar, Starch hydrolysis, Blood agar, growth at $45^{\circ} \mathrm{C}, 65^{\circ} \mathrm{C}$, in $7 \% \mathrm{NaCl}$ media and ability to grow in anaerobic condition.

\section{Identification by $16 S$ rRNA gene sequencing}

Genomic DNA was extracted according to the protocol provided

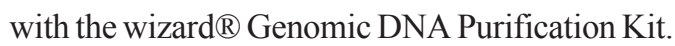

The 16S rRNA gene from the isolated DNA was amplified by Polymerase Chain Reaction (PCR) using bacterial universal primers 27F (5'-AGAGTTTGATCMTGGCTCAG-3') and 1492R (5'GGTTACCTTGTTACGACTT-3'). A reaction mixture was prepared adding $5 \mu \mathrm{l}$ of $10 \mathrm{X}$ reaction buffer having $1.5 \mathrm{mM} \mathrm{MgCl}_{2}, 1 \mu \mathrm{l}$ of $10 \mathrm{mM}$ dNTPs and $39.75 \mu \mathrm{l}$ of nuclease free water. Then each of the DNA primers was added in an amount so that the final concentration of DNA primers become $0.2 \mathrm{mM}$ in the final reaction mixture. Afterward, $2 \mu 1$ of DNA template was added along with $0.25 \mu 1$ of Taq polymerase. The final reaction volume was $50 \mu 1$. All the steps were performed on ice. The PCR reactions were performed in a thermal cycler (Applied Biosystems, USA). The PCR program initiated with an initial denaturation of template DNA at $94^{\circ} \mathrm{C}$ for 2 minutes, followed by 30 cycles: denaturation at $94^{\circ} \mathrm{C}$ for 30 seconds, annealing at $52^{\circ} \mathrm{C}$ for 30 seconds and extension at $72^{\circ} \mathrm{C}$ for 2 minutes. A single final extension was done at $72{ }^{\circ} \mathrm{C}$ for 5 minutes ${ }^{14}$.

After PCR reaction, amplification was checked by horizontal electrophoresis in $1.0 \%$ agarose slab gel in Tris -borate EDTA (TBE) buffer. $1 \mathrm{~Kb}$ plus DNA marker (Invitrogen, USA) was used to identify the amplicon size. The ethidium bromide-stained DNA bands were observed on a UV transilluminator at $365 \mathrm{~nm}$ (UV Transilluminator, Waltec). Amplified PCR products were purified by using the purification kit Wizard ${ }^{\circledR}$ SV Gel and PCR Clean-Up System. These purified PCR products were sequenced by the Sanger sequencing method using the ABI Genetic Analyzer (Model: 3700 ) in 1st BASE Laboratories, Malaysia. The sequence obtained was subjected to BLAST analysis (https:// blast.ncbi.nlm.nih.gov/Blast.cgi?PAGE_TYPE=BlastSearch) and was used for constructing a phylogenetic tree using MEGA6 software. 


\section{Effect of pH on activity of crude cellulase}

The optimum $\mathrm{pH}$ for the crude enzyme was determined by incubating crude enzyme with substrate $(1 \% \mathrm{CMC})$ prepared in appropriate buffers; $0.05 \mathrm{M}$ citrate buffer ( $\mathrm{pH} 3.0$ to 6.0$), 0.05 \mathrm{M}$ sodium phosphate buffer ( $\mathrm{pH} 6.0$ to 8.0 ), $0.05 \mathrm{M}$ Tris- $\mathrm{HCl}(\mathrm{pH} 8.0$ to 9.0 ) and $0.05 \mathrm{M}$ glycine- $\mathrm{NaOH}$ ( $\mathrm{pH} 9.0$ to 10.0). The crude enzyme mixture was added to those buffers and incubated for 30 $\min$ at $50^{\circ} \mathrm{C}$. Cellulase activity was assayed by the DNS method as previously described. The optical density (OD) was taken at $540 \mathrm{~nm}$ in a spectrophotometer.

\section{Effect of temperature on activity of crude cellulases}

The effect of temperature on the activity of cellulase was determined by incubating crude enzyme with $1 \% \mathrm{CMC}$ in $0.05 \mathrm{M}$ phosphate buffer ( $\mathrm{pH} 6.5$ ) at temperatures, including $25^{\circ} \mathrm{C}, 35^{\circ} \mathrm{C}$, $45^{\circ} \mathrm{C}, 55^{\circ} \mathrm{C}, 65^{\circ} \mathrm{C}, 75^{\circ} \mathrm{C}$ and $85^{\circ} \mathrm{C}$. Cellulase activity was assayed by the DNS method as described above.

\section{Result}

Isolation and primary screening for cellulase producing bacteria

A total 68 isolates were obtained on nutrient agar plates, out of which only 31 were capable of degrading cellulose. Their clear zone ratio is presented in figure 1 .

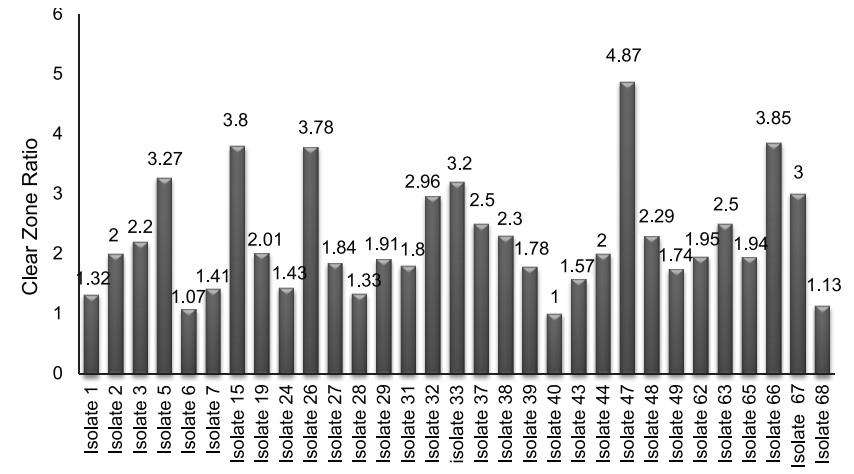

Figure 1: Ratio of clear zone diameter to colony diameter of total 31 cellulose degrading isolates.

\section{Estimation of cellulase activity and specific activity}

Out of the 31 cellulose degrading isolates, the two best isolates 47 and 66 were evaluated for their enzyme productivity in submerged fermentation process. The cellulase activities of the isolate 47 and 66 were found to be $0.101 \mathrm{U} / \mathrm{ml}$ and $0.165 \mathrm{U} / \mathrm{ml}$ respectively as shown in figure 2 . The specific activity of the isolate 66 was $0.333 \mathrm{U} / \mathrm{mg}$ while isolate 47 showed a specific activity of $0.271 \mathrm{U} / \mathrm{mg}$. This is also represented in figure 2 .

Since the isolate 66 showed higher enzyme activity along with higher specific activity, it was identified and its enzyme was characterized.

\section{Presumptive identification of the best cellulase producing isolate}

The morphological and cultural characteristics were observed and biochemical characteristics are represented in Table 1. The organism was found to be gram positive (Figure 3), facultative anaerobe and spore former. According to the biochemical tests,
Enzyme activity $(\mathrm{U} / \mathrm{ml})$

$\square$ Specific enzyme activity

(U/mg)

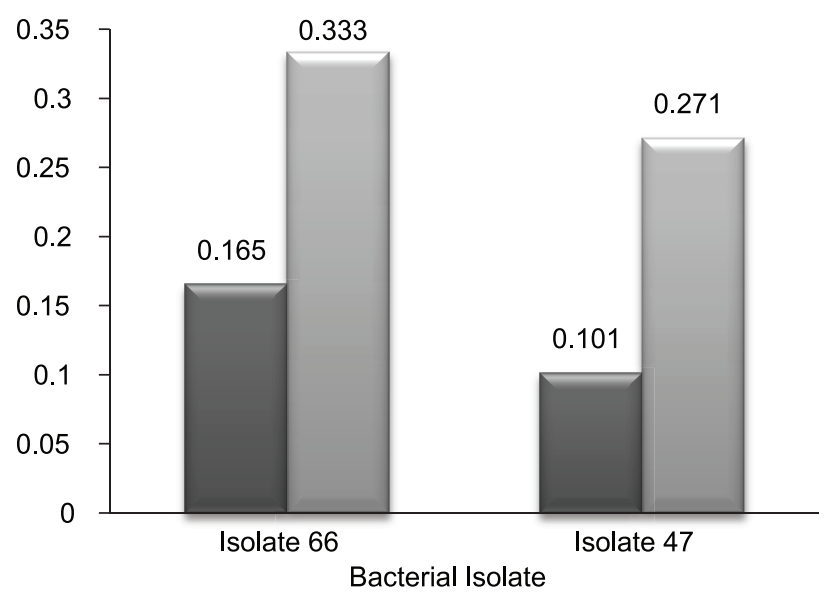

Figure 2: Cellulase activities and specific enzyme activities of isolated bacteria 47 and 66 in submerged fermentation at $37^{\circ} \mathrm{C}$.

Table 1: Biochemical reaction and characteristics of the cellulolytic bacterial isolate 66

\begin{tabular}{lccc}
\hline Biochemical tests & Results & Biochemical tests & Results \\
\hline Gram's reaction & + & Anaerobic growth & + \\
Spores formation & + & Mannitol salt agar test & + \\
Indole production & + & Starch hydrolysis test & + \\
Citrate utilization & + & Casein hydrolysis test & + \\
Voges-proskauer & + & $45 æ \% \mathrm{C}$ & + \\
Triple Sugar & Alkaline slant (red) & $65 æ \% \mathrm{C}$ & - \\
Iron agar test & and acid butt (yellow) & $7 \%$ NaCl & + \\
Urease & - & Glucose & + \\
Catalase & $+($ weak) & Lactose & - \\
Oxidase & - & D-xylose & - \\
Nitrate reduction & + & Fructose & + \\
Motility & - & Maltose & - \\
Methyl red & - & H & S \\
Gelatin hydrolysis & + & Gas & - \\
\hline
\end{tabular}

+ : indicates positive result; - : indicates negative result

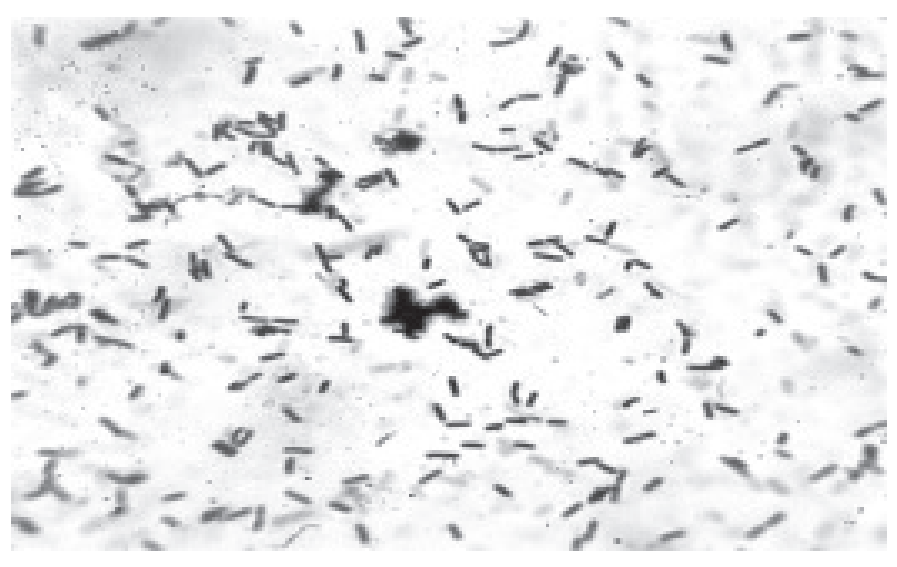

Figure 3: Gram staining of isolate 66 (positive) 
the organism belongs to the genus Bacillus as compared with Bergey's Manual of Systematic Bacteriology ${ }^{15}$.

Identification by $16 S$ rRNA gene sequencing

PCR product size was found to be just below 1650 bp by agarose gel electrophoresis (Figure 4).

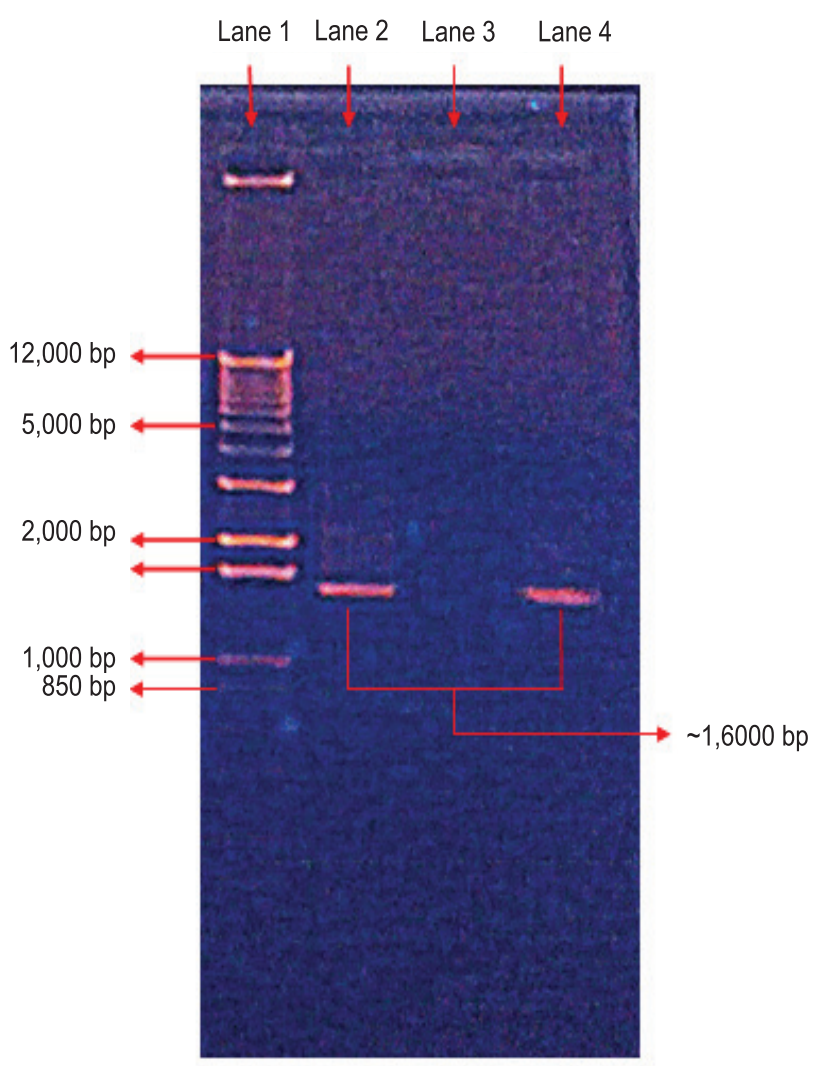

Figure 4: Agarose gel electrophoresis result of the amplification of $16 \mathrm{~S}$ rRNA gene of the isolate 66. The DNA band size was estimated to be just below1650 bp according to the $1 \mathrm{~Kb}$ plus ladder and a positive control on the other side of the sample. Lane 1: Kb plus DNA Ladder, Lane 2: $16 \mathrm{~S}$ rRNA PCR product, Lane 3: Negative control, Lane 4: Positive control.

The sequence obtained was trimmed and cleaned. Most of the homologous sequences received from NCBI nucleotide databank based on higher percentage identity (99\%) and $0.0 \mathrm{E}$-value $\left(<10^{-5}\right)$ after subjecting the corrected Fasta format of the query sequence to BLASTn program, belonged to Bacillus spp. Phylogenetic tree indicated it to be Bacillus subtilis. The higher bootstrap value (71) of the branches of Bacillus subtilis subsp. spizizenii with the query sequence (EMBOSS 001) clearly signified the stability of the branching pattern (Figure 5). Also, the distant branches of the two sequences belonging to the two different genera clearly signify having a distant relationship with the query sequence ${ }^{16}$.

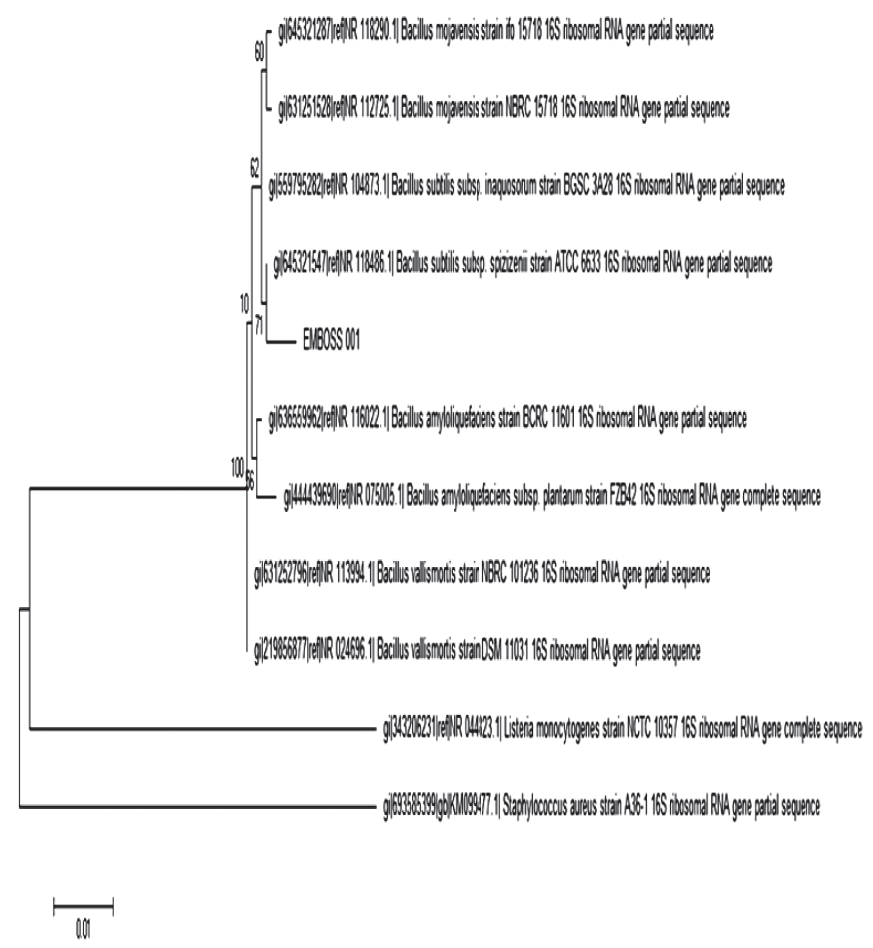

Figure 5: Molecular Phylogenetic analysis by Maximum Likelihood method illustrating the query sequence (EMBOSS 001) to be identified as Bacillus subtilis with a bootstrap value of 71 .

\section{Effect of pH on cellulase activity}

Data illustrated in figure 6 clearly indicated that the highest enzyme activity of the isolate 66 was found to be $0.494 \mathrm{U} / \mathrm{ml}$ at $\mathrm{pH}$ 5.0 suggesting that the enzyme is an acidic cellulase.

\section{Effect of temperature on cellulase activity}

Effects of temperature from $25^{\circ} \mathrm{C}$ to $85^{\circ} \mathrm{C}$ were studied. Enzyme activity was found in the range of $0.063 \mathrm{U} / \mathrm{ml}$ to $0.133 \mathrm{U} / \mathrm{ml}$. Data represented in figure 7 showed that the highest enzyme activity of isolate 66 was found to be $0.133 \mathrm{U} / \mathrm{ml}$ at $65^{\circ} \mathrm{C}$.

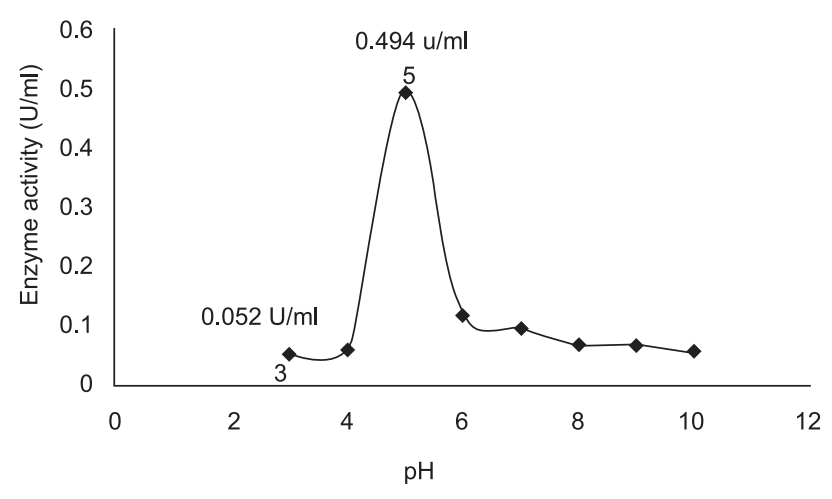

Figure 6: Effect of pH on activity of cellulase by isolate 66 


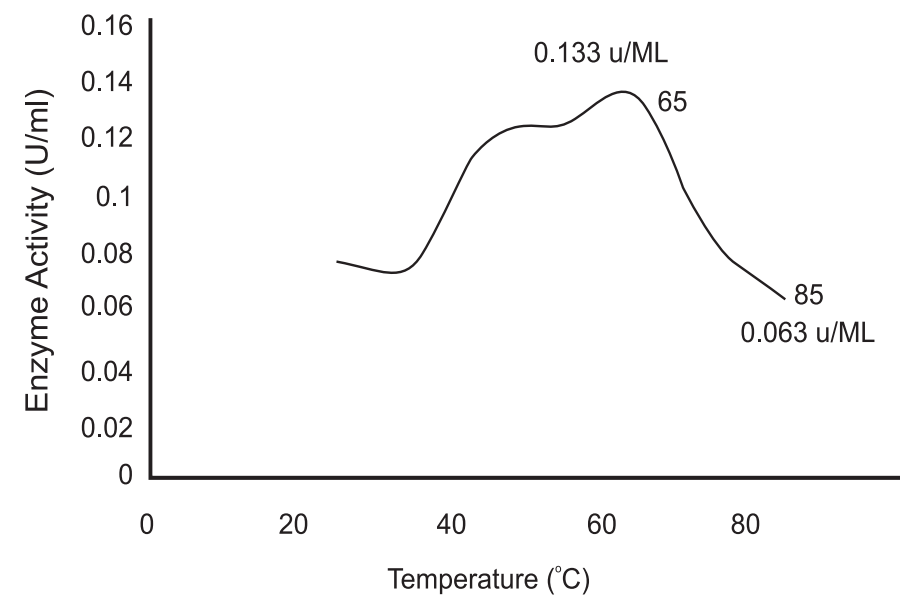

Figure 7: Effect of temperature on activity of cellulase by isolate 66

\section{Discussion}

Soil from a dairy farm was selected as the sample for the study since cow manure is considered as a desirable source of cellulase producers because of its high content of cellulosic material ${ }^{17}$. Around $50 \%$ of the bacteria showed cellulolytic activity indicating this to be a good source of cellulose degraders. Previous studies conducted with cow dung displayed similar results ${ }^{17,18}$. Sources such as farming soil, forest soil ${ }^{1}$, retting ponds and estuary ${ }^{2}$, hot springs ${ }^{19}$, wood furnishing region, sugar cane farm and water samples collected from paper industry waste and municipal waste ${ }^{6}$ are also potential sources of finding cellulolytic organisms.

Compared with the data provided by Bergey's Manual of Systematic Bacteriology, the strain turned out to be facultative anaerobe since it could grow under anaerobic condition due to its ability to ferment in the absence of $\mathrm{O}_{2}$ as an electron acceptor ${ }^{15}$. Out of the few previous studies using cow manure, one identified Bacillus subtilis with the highest homology of $100 \%$ and in another study, Bacillus circulans and Bacillus nealsonii ${ }^{17}$ were identified with a sequence identity of $99.04 \%$. Similar experiments with other samples identified Anoxybacillus flavithermus and Geobacillus thermodenitrificans ${ }^{19}$ as well as Bacillus caldoxylolyticus and Bacillus sp. strain $\mathrm{AK} 1^{20}$ as the potential cellulase producers. The optimum $\mathrm{pH}$ was close to that of most bacterial cellulases ${ }^{21}$ and a pH of 5.0 to 6.5 was found for Bacillus subtilis $^{22}$ in some studies. Also, cellulases from Bacillus subtilis subsp subtilis A-53, B. subtilis YJ1 and Bacillus strains RH68 have optimum temperatures of $50^{\circ} \mathrm{C}, 60^{\circ} \mathrm{C}$ and $70^{\circ} \mathrm{C}$ respectively ${ }^{11,23}$ which are similar to the outcome of the present study.

The isolated Bacillus subtilis was able to produce a moderate level of cellulases under thermophilic conditions from the submerged fermentation process. The typical high growth rate in Bacillus subtilis along with the ability to secrete extracellular proteins is a feature of the bacteria to be implemented in several industrial applications, for example, in biofuel, laundry, and detergent, pulp, and paper industries. Site-directed mutations and implementation of metabolic engineering can be carried out in order to develop the strain. The identification gives us the ability to control the fermentation according to the specific requirements for better industrial performance. A further analysis of the physiology of the microorganism, pre-treatment of cellulosic biomass for enhanced microbial attack, processes for costeffective production of cellulases, production of various necessary metabolites and finally utilization of the knowledge of protein engineering principle in order to increase the enzyme specific activities, process tolerance and stability can be carried out in the near future.

\section{Acknowledgment}

This research was supported by BRAC University, Bangladesh. The authors wish to take this opportunity to express sincere appreciation to the $1^{\text {st }}$ BASE laboratories, Malaysia and Invent Technologies for their assistance in $16 \mathrm{~S}$ rRNA gene sequencing.

\section{References}

1. Hatami S, Alikhani H, Besharati H and Salehra N. 2008. Investigation on Aerobic Cellulolytic Bacteria in Some of North Forest and Farming Soils. American-Eurasian Journal of Agriultural \& Environmental Sciences. 3(5): 713-716.

2. Shenkani K and Sundara C. 2015. Isolation and screening of potential cellulolytic bacteria from coir retting effluent. International Journal of Multidisciplinary Research and Development. 2(3): 27-31.

3. Yang B, Dai Z, Ding SY and Wyman CE. 2011. Enzymatic hydrolysis of cellulosic biomass. Biofuels. 2(4): 421-450.

4. Bayer EA, Henri C, Raphael L, \& Yuval S. 1998. Cellulose, Cellulases, Cellulosomes. Current Opinion in Structural Biology. 8(5): 548-557.

5. Shankar T and Isaiarasul. 2011. Cellulase Production by Bacillus pumilus EWBCM1 under Varying Cultural Conditions. Middle-East Journal of Scientific Research. 8(1): 40-45.

6. Shaikh NM, Patel AA, Mehta S, \& Patel N. 2013. Isolation and Screening of Cellulolytic Bacteria Inhabiting Different Environment and Optimization of Cellulase Production. Universal Journal of Environmental Research and Technology: 3(1): 39-49.

7. Sukumaran RK, Singhania RR and Pandey A. 2005. Microbial Cellulases- Production, applications and challenges. Journal of Scientific \& Industrial Research. 64: 832-844.

8. Sohag MHM, Hasan MM, Ahmed J, Daud SNA, Alam KMd, Amin MR, Hoq MM, Azad KA. 2013. Production and partial characterization of cellulase from Pseudomonas isolates obtained from cow dung municipal solid waste. Bangladesh Journal of Microbiology. 30(1): 11-16.

9. Khan MM, Mondal MI, and Uddin MZ. 2012. Sustainable Washing for Denim Garments by Enzymatic Treatment. Journal of Chemical Engineering. 27(1): 27-31.

10. Sharma AS, Khare K, Gupta MN. 2001. Hydrolysis of rice hull by cross linked Aspergillus niger cellulase. Bioresource Technology. 78: 281-284.

11. Irfan M, Safdar A, Syed Q and Nadeem M. 2012. Isolation and screening of cellulolytic bacteria from soil and optimization of cellulase production and activity. Turkish Journal of Biochemistry. 37(3): $287-293$. 
12. Islam M, Aktar MB and Rahman M. 2014. Determination of alphaamylase activity of Streptomyces spp isolated from Bangladeshi soils. International Journal of Interdisciplinary and Multidisciplinary Studies (IJIMS). 1(10): 167- 170.

13. Lowry OH, Rosenbrough NJ, Farr AL and Randall RJ. 1951. Protein measurement with the Folin phenol reagent. Journal of Biological Chemistry. 193: 265-275.

14. Elijah AI, Atanda OO, Popoola AR and Uzochukwu SVA. 2014. Molecular Characterization and Potential of Bacterial Species Associated with Cassava Waste. Nigerian Food Journal. 32: 56-65.

15. Logan NA and Vos PDe . 2009. Genus I. Bacillus Cohn 1872. In: (Eds.) P.D. Vos, D. Jones, NR Kreig, W Ludwig, FA Rainey, KH Schleifer, WB Whitman. Bergey's Manual of Systematic Bacteriology volume 3: The Firmicutes, Springer, 21-127.

16. Singh J, Mukhopadhyay CS, Arora JS and Kaur S. 2015. Biocomputational Characterization and Evolutionary analysis of Bubaline Dicer1 enzyme. Asian Australasian Journal of Animal Sciences. 28: 876-887.

17. Sadhu S, Saha P, Sen SK, Mayilraj S and Maiti TK. 2013. Production, purification and characterization of a novel thermotolerant endoglucanase (CMCase) from Bacillus strain isolated from cow dung. SpringerPlus. 2: 1-10.
18. Bai S, kumar MR, Mukeshkumar DJ, Balashanmugam P, Balakumaran MD and Kalaichelvan PT. 2012. Kalaichelvan, Cellulase Production by Bacillus subtilis isolated from Cow Dung. Archives of Applied Science Research. 4(1): 269-279.

19. Abdelnasser SSI and Ahmed IE. 2007. Isolation and Identification of New Cellulases Producing Thermophilic Bacteria from an Egyptian Hot Spring and Some Properties of the Crude Enzyme. Australian Journal of Basic and Applied Sciences. 1(4): 473-478.

20. Ladeira SA, Cruz E, Delatorre AB, Barbosa JB and Martins ML. 2015. Cellulase production by thermophilic Bacillus sp. SMIA-2 and its detergent compatibility. Electronic Journal of Biotechnology. 18: $110-115$.

21. Shu G, Yang H, Chen H and Yang Z. 2013. Research on Extraction and Characterization of Cellulase from Commercial Enzyme Preparation. Advance Journal of Foof Science and Technology. 5 (7): 839-842

22. Mawadza C, Hatti-Kaul R, Zvauya R and Mattiasson B. 2000. Purification and characterization of cellulases produced by two Bacillus strains. Journal of Biotechnology. 83: 177-187.

23. Yin LJ and Lin HH. 2010. Purification and Characterization of a cellulase from Bacillus subtilis YJ1. Journal of Marine Science and Technology. 18(3): 466-471. 